\title{
Housing speculation and housing price bubbles in Korea
}

\author{
Hee Soo (J oseph) Chung ${ }^{1}$ \\ Hyuk II Kwon ${ }^{2}$
}

\section{Abstract}

One of the major social and economic problems in Korea in recent years has been and still is the sustained housing prices spiral, especially since 2000. In Seoul, the ratio ofhousing pricesto household annual income is about 10 times. This is three or four times higher than the corresponding ratios in advanced countries. To make the matter worse, housing prices continue to rise rapidly in large cities including Seoul

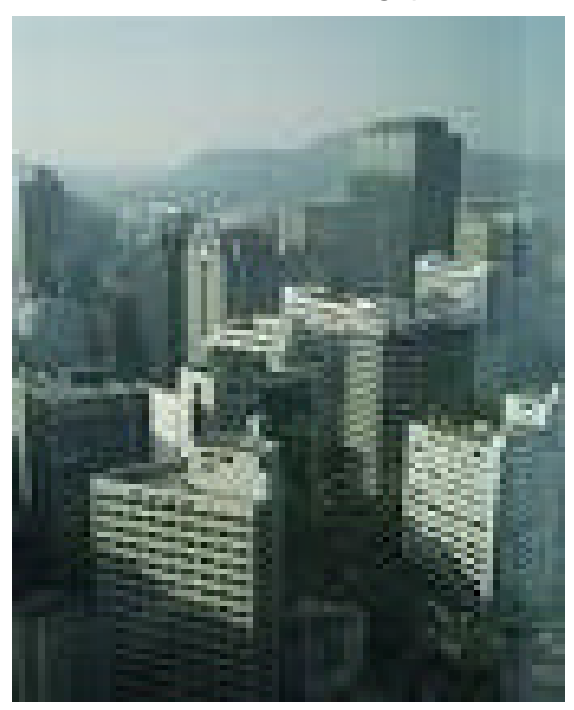
(up to twenty per cent per year lately). The excessively high housing prices results in worsening housing affordability, higher wage rates and worker's weakening desire to work. It is a common belief in Korea that speculation is the main reason for such high housing prices, thus the government has applied a series of anti-speculative measures including major increase in capital gains tax and property tax. However, these measures have not been able to eliminate speculative housing prices bubbles.

This paper is designed on one hand to evaluate the contribution of speculative activities to housing prices hike and, on the other to verify the presence of bubble in housing prices. In order to quantify the impact of speculation on housing prices, a simple devise is applied; the value of the explained variation of housing prices resulting from a regression analysis is decomposed into the percentage share of each independent variable including the variable for speculation. The presence of bubble is verified through three estimation methods: the long-run

1 Distinguished visiting professor, KDI School of Public Policy and Management ihsch2002@yahoo.com; 514-762-9203

2 Researcher at the Center for Urban Dynamics, KDI School Of Public Policy and Management 
equilibrium price approach, the fundamental market value approach and the price-income ratio approach.

This study has led to the following conclusions:

- Speculative demand has, in Gangnam District (one of the most speculative areas in Seoul) an impact on housing prices as much as five times the normal housing demand.

- There are indeed bubbles in housing prices, but their magnitudes differ somewhat depending upon the estimation methods.

- The fear that the bust of bubbles might lead to general economic collapse in Korea does not seem to be well founded; the problems of bubble in Korea appears to be much less serious the Japanese bubbles in the $80 \mathrm{~s}$ and 90 s.

- The best way to fight speculation is not to apply sudden increase in capital gains tax or any other drastic anti-speculative measures, but to implement orderly and sustained increase in the supply of housing. 


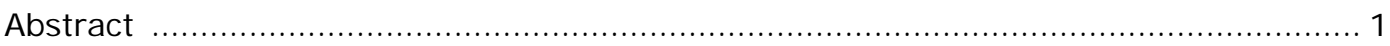

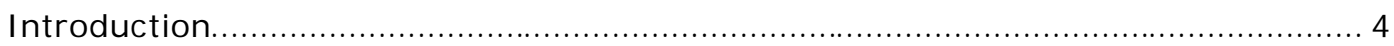

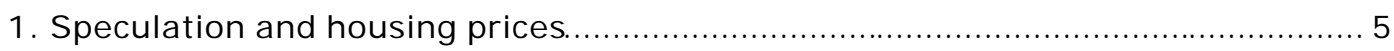

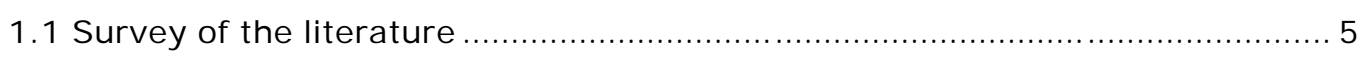

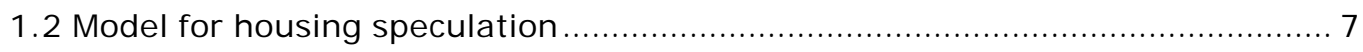

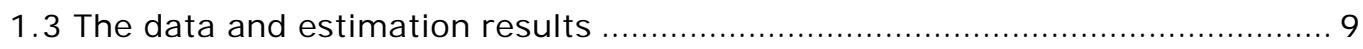

1.4 Decomposition of the estimated dependent variable.................................... 11

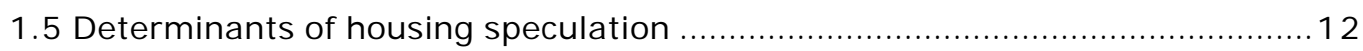

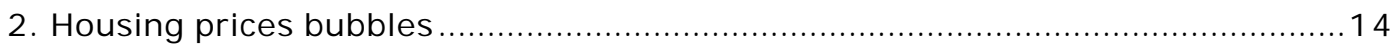

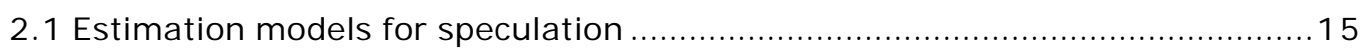

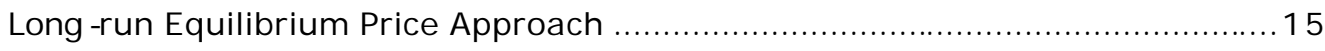

The Fundamental Market Value Approach .................................................... 15

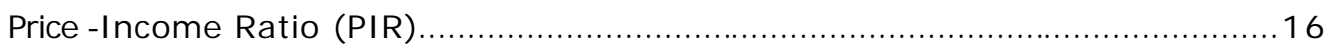

2.2. I mpact of a housing price bubble on national economy ............................. 19

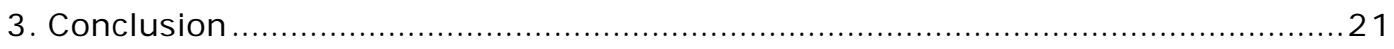

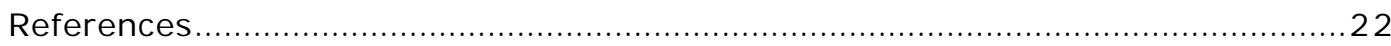

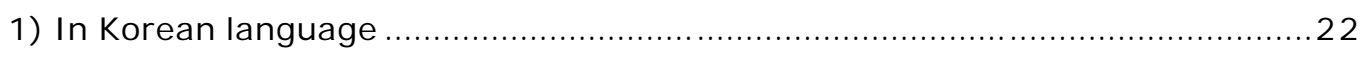

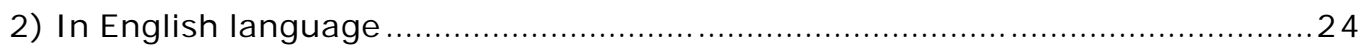




\section{Introduction}

One of the grave social and economic problems in Korea in recent years has been the never-ending housing prices spiral. Since 2000, housing prices in Seoul, Daijon and other large cities have increased by over twenty percent. The continuous increase in housing prices means worsening affordability for a great number of households for decent housing, worker's demand for higher wages, loss of competitiveness of businesses and even the weakening desire to work.

One of the methods of measuring the seriousness of housing prices is the Price to Income Ratio (PIR): the ratio of housing prices to household's annual income. The PIR for the country as a whole is about six times, while it is about ten times in Seoul as against about three or four times in advanced countries. Under these circumstances, it is quite normal to be concerned about the reasons for the housing prices hike.

Most observers are convinced that the fundamental reason for thehigh price level is housing speculation. The government has, therefore, implemented various speculative measures such as the prohibition of the sales of housing pre-sale contracts, upward adjustment of property tax, and especially drastic increase in capital gains tax. Probably because of their mistiming and the low housing demand price elasticity, these measures have not successfully stabilized prices. Housing demand price elasticity being low, a good part of the increase in the capital tax has led to further rise in housing prices.

This study has two objectives. The first objective is to verify if housing speculation is in fact a reason for the housing prices crisis and, if so, by how much. The second objective is to verify the existence of "bubble s" in housing prices caused by housing speculation. The bubble issue is of great concern in Korea since we are aware that a "bubble bust" may result in a serious economic slowdown as it happened in Japan in the 90 s.

This paper has three sections. In the first section, the role of housing speculation in the determination of housing prices is estimated through an ordinary regression analysis, while in the second, the percentage share of bubble in housing prices is estimated through three different methods. The conclusion and policy implications of the findings are summarized in the third section. 


\section{Speculation and housing prices}

\subsection{Survey of the literature}

Three approaches have been extensively used to measure real estate prices: the hedonic price approach, the real estate forecasting modeling approach and the traditional regression analysis approach. Hedonic price models have been widely used in order to measure the importance of the value that the market places oneach individual attribute of a housing unit. It views housing as a heterogeneous bundle of attributes that make up the services provided by a housing unit. The hedonic price function is estimated by regressing either rent or housing prices as dependent variable on the characteristics of a housing unit as independent variables. The partial derivatives of these functions with respect to a characteristic are the hedonic prices.

The second approach is to use forecasting modeb based on time series analysis such as Vector Auto-Regression (VAR) model or traditional Autoregressive Integrated Moving Average (ARIMA) model, which basically assumes that the future variations in real estate price depends on the past price behavior. Accordingly, the dependent variable in ARIMA models is the current real estate price and the explanatory variables are the past prices.

The advantage of using an ARIMA type of model is that it is more likely to correctly predict the short-term future price, but thed isadvantage is that one cannot add any independent variables other than the dependent variable's lagged values. Thus, the model has only limited uses in analyzing real estate market behavior and policy.

Vector Auto-Regression (VAR) model has emerged as a good substitute to avoid this problem since it combines ARIMA with traditional structural equation models. However, VAR models assume that all the variables are endogenous and each of them varies not only with its own time lag, but those of other variables. Accordingly, the more time -lag variables one may have, the more likely one may lose degrees of freedom and thus the larger the required set of data points. With a limited amount of data points, the reliability of the model becomes questionable.

Equally important is the model's assumption that all the variables are stationary. When certain variables appear to be co-integrated (detected by a unit root testing) they must be transformed by differencing procedures. Such procedures also lead to the loss of valuable information and the depletion of the data set. The other disadvantage of VAR model is that it cannothandle too many variables at once. Thus VAR models may not be the best instruments to use in the study of real estate market behavior and particularly, the effects of real estate policy on the market. 


\section{Housing speculation and housing price bubbles in Korea}

Hee Soo (Joseph) Chung and Hyuk II Kwon

However, quite a few of such models have been applied to analysis of the Korean housing market (Suh S.H, 1993; Kang W.C and Kim B.S, 1997; andKim K.S and Suh S.H 1999). They studied the structural relationship between real estate price and macro economic variables such as consumer price, economic growth and business cycle by constructing VAR model.

Son J.S and Kim K.Y. (1998.1) and Kim Y.C. (1996) analyzed the real estate price changes and found that the land price inversely varied with the yield rate of corporate bond. The lower the bond rate, the more funds tend to be invested into real estate (land) market. Also the variables that most influence land prices are the first differencing of lagged variables of land price, land transaction, and GDP. Not surprisingly land prices rise when there is high rate of economic growth and a high frequency of land transactions.

Finally there are a large number of articles on housing prices determinants through using the traditional regression analyses. They normally have two objectives in mind. The first is to test some hypothesis regarding housing market behavior or decision making behavior of individual agents. For example, a demand model is constructed to test the hypothesis that the price elasticity of housing demand is 1.0 . In this simple case, a regression model with one equation or a limited number of simultaneous equations would suffice. The other objective is to identify the real estate price determinants through estimating relevant parameters and to use them for policy impact analysis and the forecasting of real estate price and demand.

The size of model varies from one extreme to another. It could be a single equation model or a large number of simultaneous equations, depending on the study purpose. For example, Chung (1976) constructed 30 simultaneous equation model when he studied Canadian housing and mortgage market, He analyzed equilibrium price and housing rent behavior through estimating the model. He also worked on a time series model to analyze housing prices determinants as well as short and long -term factors that might affect housing construction cycle in Korea. (1984.12)

Another study b y Kim K.S et al (2003) used traditional regression models to analyze a set of determinants which explain spatial differences in housing prices. In this study, housing prices in time $t$ are assumed to be a logarithmic function of Jonsei 
price $^{3}$ total money flow, and the rate of change in lagged prices. The model results turned out as predicted; housing prices increase with Jonsei prices and with the increase in money flow. An interesting point is that the lagged price of housing is considered as reflecting the expected capital gain s. In other words, the variable represents speculative motivation.

The study also illustrates the counter-cyclicity of housing prices and thestock prices. Investment funds move from housing to the stock market when stock price rises, resulting in a decrease in housing prices.

\subsection{Model for housing speculation}

This study also opts for a traditional regression model for a few reasons. One is the possible loss of valuable information by using traditional time series analysissuch as ARIMA and VAR models. Secondly, one cannot incorporate into ARIMA and VAR models a large enough number of market and policy variables which may better explain changes in real estate prices.

The model for the present study is based on both theories of excess demand and cost push in real estate market. Figure 1 below illustrates this point. Suppose that P1 is the price of real estate in time $t$ and at this price level the quantity demanded for real estate is $\mathrm{OH} 2$ and the quantity supplied is only $\mathrm{OH} 1$. Thus, the excess demand is represented as $\mathrm{OH} 2-\mathrm{OH} 1=\mathrm{H} 1 \mathrm{H} 2$. If the market normally behaves, the price will continuously rise until it reaches an equilibrium price of $\mathrm{P} 2$ in time $t+1$. Suppose also that the real estate cost increases due to an increase in land price s (land as an input for real estate property). This will push the supply curve upward from $S$ to $S$ and one ends up with a new equilibrium price of $\mathrm{P} 3$. Consequently real estate price $S$ move from $P 1$ to $P 3$ and the difference between $P 2$ and $P 1$ results from excess demand and that between $\mathrm{P} 3$ and $\mathrm{P} 2$, from cost push. Thus, housing prices hike s are assumed to be caused by both factors of demand pull and cost push simultaneously. $60 \%$ of the dwelling price. Yield on the investment of J onsei is the rental income for the owner. The tenant gets back the fund when he or she leaves the premises. This rent- prepayment system is uniquely Korean. 
Figure 1: Mechanism of housing prices increase

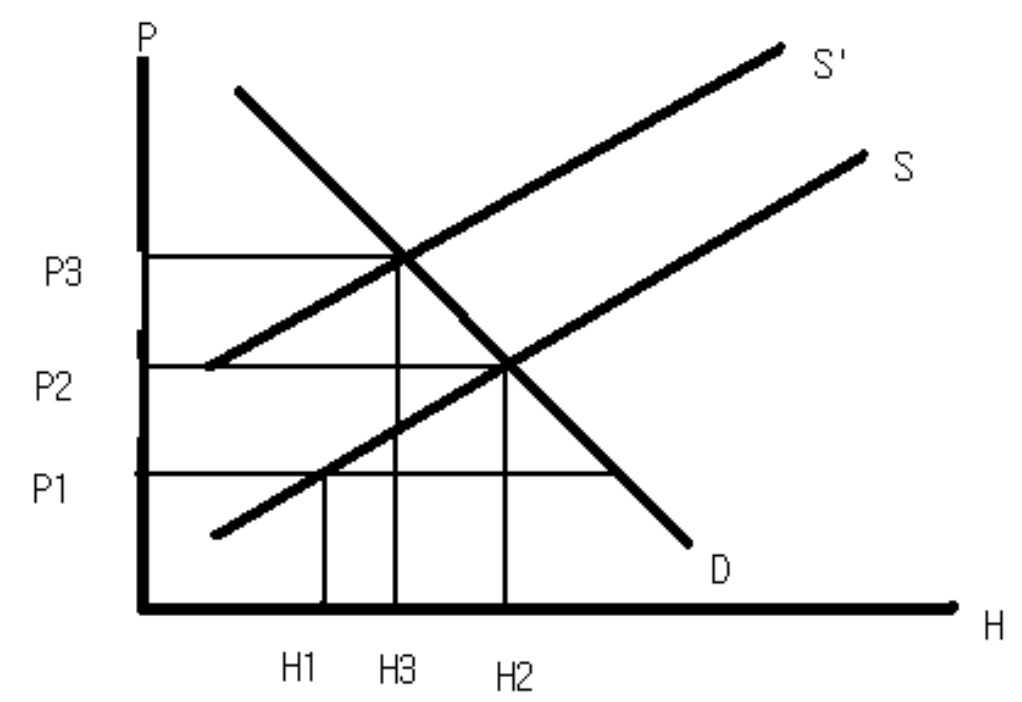

The model to beestimated is as follows;

$$
\begin{array}{ll}
\mathrm{P}_{\mathrm{t}}= & \mathrm{a}_{0}+\mathrm{a}_{1} \mathrm{I}_{\mathrm{t}}+\mathrm{a}_{2} \mathrm{P}_{\mathrm{t}-1}-\mathrm{a}_{3} \mathrm{i}_{\mathrm{t}}-\mathrm{a}_{4} \mathrm{H}_{\mathrm{t}-1}+\mathrm{a}_{5} \mathrm{C}_{\mathrm{t}} \\
\mathrm{P}_{\mathrm{t}}: & \text { housing prices in time } \mathrm{t} \\
\mathrm{I}_{\mathrm{t}}: & \text { household income in time } \mathrm{t} \\
\mathrm{I}_{\mathrm{t}}: & \text { yield rate of housing investment at } \mathrm{t} \text { ( bond yield) } \\
\mathrm{P}_{\mathrm{t}-\mathrm{1}}: & \quad \text { expected price change at } \mathrm{t}-1 \\
\mathrm{H}_{\mathrm{t}-1}: & \text { housing stock at } \mathrm{t}-1 \\
\mathrm{C}_{\mathrm{t}}: & \quad \text { housing cost (land cost, construction cost, etc }) \text { at } \mathrm{t}
\end{array}
$$

This model assumes that housing demand is a combination of "normal" demand and "speculative" demand. Normal demand is assumed to depend on income and bond yield. As household income increases and bond yield s falls, the normal consumer would allocate the increased income and the proceeds of the sales of bond to the purchase of a house to live in. The normal consumer, being risk-averse, would buy his house on the basis of such determinants as income increase and bond yield s. On the other hand, the speculative consumer- assumed to be a risk taker-will purchase a house on the basis of expected (but unknown) increases in housing prices. 
This model is estimated through OLS method and applied to four different spatial units: Korea, Kyunggi province, Seoul and Gangnam district. It is expected that the relative importance of speculation increases as one moves from Korea to Gangnam district. As pointed above, Gangnam is known to be experiencing the most active real estate speculation.

\subsection{The data and estimation results}

The Data used are the comprehensive index of housing prices estimated by Kookmin Bank (formerly Korea Housing Bank) covering the period, $19871 \mathrm{Q}-2003$ 4Q. Table 1 presents the estimates of the regression analysis where housing prices variation is regressed on a number of independent variables: the per capita GDP as a proxy for income, the yield of 3-year maturity corporate bond, the land price representing construction cost, the expected rate of return on housing investment represented by lagged price variable and housing construction permit representing housing stock. Quarterly data were used for the analysis. Also included in this model were two dummy variables, one for the third quarter of 1990 and, the other, the first quarter of 2002. The dummies were used to observe any changes in price by the announcement of anti-speculation measures. All the independent variables are lagged. The number of lags is selected empirically. The first dummy variable (1990 $3 \mathrm{Q}=1.0$ ) reflects the impact of anti-speculation policy which included the upper ceiling on land ownership, tax on non-realized capital gains and development tax. The second dummy $(20021 \mathrm{Q}=1.0)$ represents another similar government anti-speculation measure s accompanied by the designation of "speculative zones." 


\section{Housing speculation and housing price bubbles in Korea}

Hee Soo (J oseph) Chung and Hyuk II Kwon

Table 1: Housing price (the dependent variable)

\begin{tabular}{|c|c|c|c|c|}
\hline Independent Variable & Korea & Kyunggi & Seoul & Gangnam \\
\hline Constant & $\begin{array}{l}-0.4364 \\
(-1.070)\end{array}$ & $\begin{array}{l}-0.4245 \\
(-1.3198)\end{array}$ & $\begin{array}{l}-0.3855 \\
(-1.432)\end{array}$ & $\begin{array}{l}-0.4804 \\
(-1.498)\end{array}$ \\
\hline GDP $(t-1)$ & $\begin{array}{c}0.0751 \\
(1.529)^{*}\end{array}$ & $\begin{array}{r}0.0712 \\
-1.2528 \\
\end{array}$ & $\begin{array}{c}0.0624 \\
-1.2664 \\
\end{array}$ & $\begin{array}{c}0.0847 \\
(1.4760) *\end{array}$ \\
\hline $\begin{array}{l}\text { Rate of Yield of 3-year } \\
\text { Industrial Bond (t-1) }\end{array}$ & $\begin{array}{c}-0.0311 \\
(-1.8343) * *\end{array}$ & $\begin{array}{c}-0.0251 \\
(-1.1702)\end{array}$ & $\begin{array}{c}-0.0367 \\
(-2.0159) * * *\end{array}$ & $\begin{array}{c}0.0357 \\
(-1.6235)^{* *}\end{array}$ \\
\hline Land Price (t-1) & $\begin{array}{c}0.1272 \\
(2.4604)^{* * *}\end{array}$ & $\begin{array}{c}0.1633 \\
(2.4636) * * *\end{array}$ & $\begin{array}{c}0.1689 \\
(3.0156)^{* * *}\end{array}$ & $\begin{array}{c}0.1949 \\
(2.9216) * * *\end{array}$ \\
\hline $\begin{array}{l}\text { Expected housing prices } \\
\text { (t-1) }\end{array}$ & $\begin{array}{c}0.9033 \\
(21.1467)^{* * *}\end{array}$ & $\begin{array}{c}0.9318 \\
(20.5817)^{* * *}\end{array}$ & $\begin{array}{c}0.9324 \\
(22.6109) * * *\end{array}$ & $\begin{array}{c}0.9196 \\
(22.3515)^{* * *}\end{array}$ \\
\hline $\begin{array}{l}\text { Housing Building Permit } \\
(\mathrm{t}-1)\end{array}$ & $\begin{array}{c}-0.0126 \\
(-2.2216)^{* * *}\end{array}$ & $\begin{array}{c}-0.0136 \\
(-1.9971)^{* *}\end{array}$ & $\begin{array}{c}-0.0136 \\
(-2.3378)^{* * *}\end{array}$ & $\begin{array}{c}0.0183 \\
(-2.6000) * * *\end{array}$ \\
\hline D $19903 Q$ & $\begin{array}{c}0.9303 \\
(1.6050)^{*} \\
\end{array}$ & - & - & - \\
\hline D 2002.1Q & $\begin{array}{c}1.2217 \\
(2.1901) * * * \\
\end{array}$ & $\begin{array}{c}1.654 \\
(2.3264) * * * \\
\end{array}$ & $\begin{array}{c}1.4598 \\
(2.4316)^{* * *} \\
\end{array}$ & $\begin{array}{c}1.9482 \\
(2.6913) * * * \\
\end{array}$ \\
\hline$R^{2}$ & 0.926 & 0.903 & 0.923 & 0.921 \\
\hline $\mathrm{F}$ & 100.27 & 86.058 & 111.355 & 108.182 \\
\hline $\mathrm{t}$ values in parenthesis are & \multicolumn{4}{|c|}{$\begin{array}{l}* \text { - significant at } 10 \% \text { probability } \\
* * \text { - significant at } 5 \% \text { probability } \\
* * * \text { - significant at } 1 \% \text { probability }\end{array}$} \\
\hline
\end{tabular}

The regression analysis results appear quite reliable. The adjusted coefficient of determination exceeds $90 \%$ for all areas studied. The traditional Durbin -Watson test is not applicable here, for one of the independent variables is a lagged dependent variable. The variation in GDP has relatively low Evalue, although it shows the expected positive sign. It is significant at $10 \%$ probability level for Korea and Gangnam. For Kyunggi province and Seoul, it is significant at $20 \%$ probability level. This may suggest that GDP is not a good proxy variable for household income or the impact of normal demand on price is rather weak. The bond yield variable shows an expected minus sign and is significant for all the areas under study with the exception of Kyunggi province. The combined performance of GDP and bond yield seems to indicate that what determines housing prices hike in Korea is not "normal" demand but "speculative" demand. In fact, lagged price variable representing "speculative" demand shows an expected sign and has the highest tvalue. The housing permits variable representing housing supply shows, as expected, a minus 
sign and is highly significant. Thus, given housing demand, housing prices variation is inversely related to housing supply. Finally, land cost shows an expected sign and very significant suggesting that it also exerts a strong impact on housing prices inflation. The first dummy variable representing the anti-speculation measures adopted early 1990 is significant at $10 \%$ probability level, while the second dummy variable reflecting these (e.g.: designation of speculative zone) adopted early 2002 is very significant at $1 \%$ probability level. Both variables show a plus sign implying that they failed. If the measures had been successfulwe would have a negative sign. The performance of the dummy variables seems to indicate that the anti-speculation measures are either ineffective or that they may take a longer period to become effective .

\subsection{Decomposition of the e stimated dependent $v$ ariable}

The share of an independent variable in influencing dependent variable within a certain period of time can be measured with the model below.

$$
\mathrm{W}_{\mathrm{i}}=\sum_{t=1}^{T} \mathrm{~b}_{\mathrm{i}} \mathrm{X}_{\mathrm{it}} / \sum_{t=1}^{T} \mathrm{Y}_{\mathrm{t}}
$$

Where

$$
\begin{aligned}
& W_{i} \quad \text { share of } X_{i} \text { in the variation of explained } Y \text { at time } t \\
& b_{i}: \quad \text { regression coefficient of } X_{i} \\
& X_{i t}: \quad X_{i} \text { at time } t, \\
& t: \quad 1,2, \ldots T \\
& Y_{t}: \quad \text { estimated value of the housing prices at time } t
\end{aligned}
$$

This method of estimating the impact of independent variables has the adva ntage in that it allows us to observe how the impact of a given independent variable varies during different time period. The numerator of the model shows that part of the explained variation of the dwelling price which is attributable to a given independent variable, while the denominator is shows the total explained variation of the dwelling price.

The results of the analysis are shown in table 2 below. During the period of 71 quarters between the first quarter of 1987 and the second quarter of 2003, the percentage share of the per capita GDP and bond yield representing "normal" 
demand for Korea, as a whole, is $86 \%$, as against 35\% for Kyunggi; $34 \%$ for Seoul and $24 \%$ for Gangnam district.

Table 2: Degree of Contribution to housing price inflation (\%)

\begin{tabular}{|lcccc|}
\hline & Korea & Kyunggi & Seoul & Gangnam \\
\hline $\begin{array}{l}\text { 1. Total estimated housing price variation } \\
\text { 2. Contribution of each independent variable }\end{array}$ & 100 & 100 & 100 & 100 \\
$\quad$ GDP & 55 & 24 & 19 & 16 \\
$\quad$ Bond yield & 31 & 11 & 15 & 9 \\
$\quad$ Expected housing prices & 107 & 92 & 97 & 94 \\
$\quad$ Land price & 42 & 25 & 23 & 16 \\
$\quad$ Home building permit & -38 & -19 & -17 & -14 \\
3. Ratio of speculative demand to normal & 1.24 & 2.62 & 2.85 & 3.91 \\
\hline
\end{tabular}

Note: The sum of the independent variables' weights cannot be 100 because of the constant

On the other hand, the rate of increase in home building permit contributes to price stabilization by $38 \%$ (Korea), 19\% (Kyunggi), 17\% (Seoul) and 14\% (Gangnam). Land cost also contributes significantly to housing prices $h$ ike accounting for between $16 \%$ and $42 \%$ depending on the area. Interestingly, the percentage share of speculative demand in housing prices spiral is very high. The share of expected housing prices which represents speculative demand is much more powerful: $107 \%$ for Korea, as a whole, $92 \%$ for Kyunggi, $97 \%$ for Seoul and $94 \%$ for Gangnam area. In order to investigate more precisely the relative weight of speculative demand variable, the share of the speculative demand is divided by that of "normal" demand. The ratio of speculative demand (expected housing prices) to normal demand (GDP and bone yield) for Korea is 1.24 , but it jumps to 2.6 times for Kyunggi province, 2.85 times for Seoul and 3.91 times for Gangnam area.

\subsection{Determinants of housing speculation}

What are the causes of the housing speculation? There seem to be many reasons why speculation has occurred particularly over the last two years. There are five generally accepted scenarios: low rate of interest rate on savings; expansion of money supply (or increase in liquidity); availability of home mortgage loan funds; rising demand for housing and demand-supply mismatch; and government measures to revitalize the economy. These factors combined would have drastically increased the expectation for large windfall capital gains from housing investment.

The interest rate on short-term bank deposit fell from $13.3 \%$ in 1998 to $4.7 \%$ in 2002, and afterwards it has gradually dropped down to $3.9 \%$ in August 2003. A fall 
in interest rate has directly affected the real estate market in many ways. It resulted in the reduction of the Jonsei value ${ }^{4}$ from the standpoint of the landlord, who would then switch to monthly rental, and this would have caused the number of Jonsei apartment stock to decrease. And the subsequent effect was the rise in Jonsei rent and more renters would have purchased homes rather thanpaying high J onse i rent. In fact, the ratio of J onsei over the purchase price rose from $60 \%$ in J a nuary 2000 to $68 \%$ in January 2002 . The whole cycle that started with low rate of interest would eventually be ended up with rise in the demand for owner-occupied dwellings. This would obviously push the housing prices up.

Secondly, the fall in interest rate would reduce the financial burden of interest payment on the part of the consumers, which would have led to the increase in the demand for home mortgages. More households would have purchased homes through mortgage financing, which would also have pushed the demand for housing and eventually raise the price of housing. In general a fall in interest rate tends to make investors prefer real estate to financial assets, because the former yields relatively higher rate of return than the latter. Theoretically, if interest falls, the present value of the future income streams increases. Asset value is computed simply by dividing future income by interest rate. Therefore, if interest rate falls, the real estate value goes up, other things being equal, and again it stimulates speculative housing demand and pushes housing prices up.

A substantial increase in money supply is another important factor that would have significantly contributed to housing pricesspiral. Too much money has been supplied since the financial crisis of 1997-1998 in part to stimulate the depressed economy. Ever since 1999, the rate of increase in M3 has exceeded that of GDP. The international trade surplus has also contributed to the excess supply of liquidity. It amounted to $\$ 41.4$ billion in 1998 and $\$ 44.9$ billion in 1999 .

Another factor that might have caused the housing prices inflation is a record rise in both home mortgage and personal lending. Personal borrowing became easy due to low rate of interest and availability of funds to go around. Financial institutions carried a sufficiently large amount of liquid funds for lending, but private firms hesitated to borrow money for the expansion of investment in capital equipment because of uncertainty about the economy. Therefore a huge amount of funds remained idle or "dormant." Meanwhile, these financial institutions concentrated on 
home mortgage loans, as they were considered profitable and relatively risk-free. Besides, those who borrowed money were upper-middle class households and credit worthy. Accordingly, a large amount of liquid money has flown into the housing market, especially the Gangnam submarket where the housing prices was expected to continuously rise. The amount of home mortgage loans outstanding held by the financial institutions almost doubled within a year from 38.2 trillion won in 2000 to 63.5 trillion won in 2001. And the figure reached over 125 trillion won in 2002. Thus, the availability of credit led to the increase housing demand, which in turn contributed to the inflation of housing prices.

Finally the government's expansion policy after the financial crisis of 1997 relied heavily on the housing sector as the best way of revitalizing the national income and creating jobs, because the multiplier effect of housing investment was estimated to be as high as 1.9. The government relaxed, liberalized or even repealed various harsh anti-speculative measures. For instance, it was allowed to sell the pre-sale contract to speculators. ${ }^{5}$ The system of new dwelling price control was abolished. The regulation on mandatory percentage ratio of supplyin $\mathrm{g}$ small sized apartment units (for example, from $70 \%$ down to $40 \%$ ) was relaxed. Moreover, land use regulations within the green belt area that surrounded large metropolitan areas were relaxed. In addition, various financial and tax incentives were provided for both ordinary investors and developers alike to invest money into housing and land developments. In particular home buyers were given incentives to borrow money for home purchase at subsidized interest rate and write off interest payments from income taxes. These highly expansionary policy packages have clearly resulted in housing prices inflation.

\section{Housing prices bubbles}

Real estate price bubbles raised some heated discussion among the academics in the 90 's , when Japanese economy experienced "bubble to bust" which led the country to a subsequent durable financial crisis. Many scholars and the mass media claimed that the recent housing of savings is achieved, the saver is authorized to buy the apartment under certain conditions and the saver gets the pre-sale deed. Under normal conditions, the saver cannot sell it. 
prices escalation taking place in Gangnam area would be a symptom of a price bubble, and warned that if unchecked, it would eventually lead to bust and to a serious asset deflation as observed in Japan in the 1980sand Thailand in the 1990s.

This study is intended to explore and further elaborate on a few propositions with regard to real estate price bubble. What is bubble? And if it does exist, how serious is it? Is it serious enough to go bust in a foreseeable future? Are there any policy measures that can prevent the price bubble or the bust of bubble, if bubble really exists? These are some of the questions that this study examines.

Generally price bubble is defined as an unusually large difference between actual prices and theoretical or normal prices. No matter how we define it, bubble is an abnormal and irregular price spike as pointed out by Frankel and Rose (1996). But the question then is; what is the normal price level? Theoretically normal price is the one that is determined under the normal market conditions; in other words as Garber (1988) pointed out, bubbles would not exist if the housing market behaved normally.

\subsection{Estimation m odels for speculation}

There are several ways of estimating bubble effects: the long-run equilibrium price approach, the fundamental market value approach and the price-income ratio approach

Long-run Equilibrium Price Approach

Several studies (Samsung Research Institute, 2003. 5; Korea Deposit Insurance Corp. 2002; Kim, Kyung Hwan, 2003) assume that variation in such macro economic variables as GDP and consumer price index reflect a long-run equilibrium housing prices. This approach can be summarized;

$$
\begin{array}{ll}
\mathrm{Bt}(\%)= & \mathrm{Bt} / \mathrm{Pt}=\% \text { share of } \mathrm{Bt} \\
\mathrm{Bt}: & \text { the amount of bubble in year } \mathrm{t} \\
\mathrm{Pt}: & \text { the rate of change in actual price in } \mathrm{t} \\
\mathrm{GDPt}: & \text { the rate of change in GDP in } \mathrm{t}
\end{array}
$$

The Fundamental Market Value Approach

This approach is based on the assumption that deviation fro $m$ the fundamental market is "abnormal" and bubble. The fundamental market value is the present 
value of future stream of benefit (income on utility) coming from the dwelling. This approach can be summarized as follows:

$\begin{array}{ll}B_{t} \quad= & P_{t}-E\left(P_{t}\right) \\ E\left(P_{t}\right)= & R / I \\ R: & \text { income (or utility) stream of real estate } \\ \mathrm{i}: & \quad \text { discount rate }\end{array}$

Monthly rent (income) was estimated as follows: Jonsei rent is converted into monthly rent by applying $0.9 \%$ of interest rate. ${ }^{6}$ The discount rate is $1 / 11$ of the annual yield on 3 -year co rporate bond.

Price-Income Ratio (PIR)

Some studies (Flood, Carber, 1980; Samsung Research Institute, 2003) assume that the "normal" housing prices should not exceed excessively the household annual income. To be more precise, the normal housing prices should be the average PIR plus one standard deviation. If we assume normal distribution of PIR, the assumed probability range would cover $85 \%$ of the PIR sample. This approach can be summarized.

$$
\begin{aligned}
\mathrm{B}_{\mathrm{t}} & =\mathrm{P}_{\mathrm{t}}-1.5 \sigma(\mathrm{PIR}) \\
\sigma & =\text { standard deviation of } \mathrm{PIR} \\
\mathrm{PIR} & =\text { price -income ratio }
\end{aligned}
$$

Data used for the long-run equilibrium price approach are the comprehensive housing prices indices compiled by Kookmin Bank, covering the period of the first quarter of 1997 through that of 2002, whereas those for the fundamental market value approach and the PIR approach are the actual housing prices comprising mainly apartment prices provided by Budongsan Bank covering the period of the first quarter of 1997 through that of 2003.

\footnotetext{
${ }^{6}$ Normally, it is assumed that the annual rate of return of J onsei funds is $11 \%$.
} 


\section{Housing speculation and housing price bubbles in Korea}

Hee Soo (Joseph) Chung and Hyuk II Kwon

The estimates of bubble are summarized in Table 3, 4 and 5. Table 3 shows the share of bubble estimated according to the long-run equilibrium price approach. It is very high: 36\% (Gangbuk), 61\% (Seoul) and 71\% (Gangnam). The bubble in Gangnam is twice that of Gangbuk. It is interesting to note that the housing prices bubble reached the peak in the fourth quarter of 2001 to fall substantially in the first quarter of 2002. These results appear much more pronounced than what one might have expected. The high level of bubble shown here is explained by the fact that it refers to the variation of the housing prices not the absolute price level. Therefore, in order to estimate bubble's share in the housing prices itself, one has to make downward adjustment of the bubble estimated by the long -run equilibrium price by applying the rate of price variation. Estimated shares of bubble in the price are shown in bracket. It seems that the bubble's share in the absolute level of housing prices is very low varying between $2.6 \%$ and $5.4 \%$ even in Gangnam area. These findings may be explained by the fact that the data used cover the price of all dwellings. If one used data on price of apartments alone, one would have obtained larger share of the bubble.

Table 3 Estimate of bubble effect in the variation of housing prices

Long term equilibrium approach

\begin{tabular}{|ccccc|}
\hline Period & Seoul & Gangbuk & Gangnam \\
\hline $20013 \mathrm{Q}$ & $0.56(0.017)$ & $0.32(0.006)$ & $0.66(0.026)$ \\
$20013 \mathrm{Q}$ & $0.75(0.033)$ & $0.60(0.016)$ & $0.81(0.047)$ \\
$20021 \mathrm{Q}$ & $0.61(0.027)$ & $0.36(0.012)$ & $0.71(0.054)$ \\
\hline
\end{tabular}

Note: Figures in bracket represent the share of bubbles in the absolute level of the price.

The estimates of housing prices bubble according to the fundamental market value are summarized in Table 4. In Gangnam-gu, the bubble's share in the price rose from $14 \%$ in the 3 rd quarter of $2001,16 \%$ in the 4 th quarter of 2002 to as much as $23 \%$ in the 1st quarter of 2002. In Socho-gu, on the other hand, the bubble's share rose from $7 \%$ in the 3 rd quarter of $2001,9 \%$ in the 4 th quarter of 2001 to $17 \%$ in the 1 st qua rter of 2002. Finally, in Songpa-gu, it rose from 17\% in the 3rd q uarter of 2001, $22 \%$ in the 4 th quarter of 2001 to $29 \%$ in the 1st quarter of 2002. 
Table 4 Estimate of bubble effects by the fundamental value approach

\begin{tabular}{|lccc|}
\hline & Gangnam-gu & Socho-gu & Songpa-gu \\
\hline $20013 \mathrm{Q}$ & 0.14 & 0.07 & 0.17 \\
2002 & 0.16 & 0.09 & 0.22 \\
$20021 \mathrm{Q}$ & 0.23 & 0.17 & 0.29 \\
\hline
\end{tabular}

Note: The three Autonomous Districts(Gu) are a part of Seoul located in the southern side of Han river. These districts are known to have, in recent years, experienced most serious housing speculation in Korea.

Finally, the estimates of the bubble by the price -income ratio approach are shown in Table 5. The average PIRs are 15.62 times (Gangnam-gu), 15.39 times (Socho-gu), 12.81 times (Songpa-gu). The standard deviations of PIR are 2.04, 2.10 and 1.66 respectively for Gangnam-gu, Socho-gu and Songpa-gu. Hence, the critical PIR for the three Gus are 17.65, 17.50 and 14.48, respectively. According to the data examined, over the period, the 1st quarter of 1997 through that of 2003, the actual PIR exceeded the critical price only, as shown in the Table, in the 1st quarter of 1997 , 1998 and 2002. The resulting shares of the bubble in PIR for the 1st quarter of 2003 are 13\% (Gangnam-gu), 9\% (Socho-gu) and 15\% (Songpa-gu)

Table 5 Estimate of Bubble by the PIR Approach

\begin{tabular}{|c|c|c|c|}
\hline Period & Gangnam-gu & Socho-gu & Sonpa-gu \\
\hline $19973 Q$ & 0.076 & 0.113 & 0.064 \\
\hline $19983 Q$ & 0.039 & 0.055 & 0.012 \\
\hline $20023 Q$ & 0.13 & 0.09 & 0.146 \\
\hline
\end{tabular}

The findings related to housing prices bubble may be now summarized. First, the magnitude of the bubble varies somewhat depending upon the estimate methods used. The fundamental market value approach appears to yield the largest magnitude of bubble, being followed by the PIR approach and the bng-run equilibrium price approach. However, the last approach may be an underestimation of the bubble, because the data used covered all types of dwellings, whereas, in the other two approaches, prices of apartments were used. Second, the view that the housing bubble is more than $40 \%$ of the housing prices and of alarming proportion appears to be a little exaggerated. Third, of the three most speculative Autonomous Districts in Seoul, it is Songpa-gu which has experienced the largest housing prices bubble. 


\subsection{I mpact of a housing price bubble on national e conomy}

Real estate experts, reporters, politicians and even ordinary people are wondering about the possible impact of real estate bubble on the national economy and many are concerned about the possibility of repeating Japanese experience. It appears that such worries are not well founded. It must be remembered that housing situations in the two countries were very different. For instance, the price bubble in Japan initially started with land and spread throughout the country, but the bubble that Korea went through recently was limited largely to housing in Gangnam area and Inchon and Daejun city areas to a lesser extent. But similarities exist with respect to financial situation, i.e., the low interest rate and abundance of liquid money, and also the recovery policy that stimulated domestic consumption through extension of personal credit. In both countries the financial institutions "competitively" expanded personal loans, particularly mortgage loans. But it should be noted that the loan to value ratio (LTV) in J apan was as high as $120 \%$ on average, while in Korea it was only $20 \%$ to $40 \%$ at the maximum, implying that the Korean financial institutions would be significantly less venerable than the Japanese co unterparts, even if asset deflation may occur.

What impact such a price bubble might have on national economy? As emphasized, bubble means abnormal or irregular increase in real estate price. Bubble has a long history in capitalistic countries and it has a ffected national economy either in positive or negative way. For instance, the history saw to it that the railroad and canal bubbles in Great Britain during the industrial revolution contributed to the expansion of major transport infrastructure facilities (Kindleberger, 1978). More recently the price bubble arising from the memory system of computer in the U.S. is known to have revolutionized the computer industry.

Nonetheless, the real estate bubble, particularly the housing prices bubble, has bad connotations, because it is known that it would do more harms than good to the economy. It causes housing costs to rise, and, in this process, the most adversely affected are the poor people and salaried workers who live on fixed income. Also hurt are those whosave money to purchase a home, because there is no way to catch up with the price increase. It is also true that housing prices bubble is partially, if not totally, correlated with labor disputes, for labor unions claim for a raise of wages and salaries to cover the additional costs of living resulting from high priced housing. In other words, housing cost may provoke labor dispute. And such a raise of wage eventually undermines not only the competitiveness of the given industry, but also the national competitiveness itself. Even more serious would be the scenario of long lasting economic slump as a result of "bust" and corresponding asset deflation that Japan experienced over the last ten years. 


\section{Housing speculation and housing price bubbles in Korea}

Hee Soo (Joseph) Chung and Hyuk II Kwon

Once bubble busts, the price of real estate goes down dramatically and in particular, the value of mortgage collateral falls to the extent that it becomes well below the amount of loans outstanding. If the LTV ratio is high as it was in Japan, there is no way to recover the loan and consequently, many financial institutions would go bankrupt. And those remaining in business would not only hesitate to issue new loans, but also request early repayments from the borrowers. The incidences of personal bankruptcy would then be on the rise, leading to substantial reduction of consumption and production as well, and eventually to an increase in unemployment. Such a vicious circle would continue for a long time and if so, the economy would suffer from depression. This scenario is exactly what happened in Japan in 1990's as a result of real estate bust.

Is there any sign of such a "malignant" real estate bubble in Korea? The answer is not yet! The magnitude of the bubble's effects on the economy may be determined by its level and depth. In Japan, the bubble did spread so widely and deeply that almost every economic agent, household, firm and the government alike, felt its effect badly. It was also spatially wide spread. But the bubble effects in Korea have been limited to only a few areas and to small number of economic agents. Bubble occurred only in a few housing sub-markets such as Gangnam and its surrounding areas, and only a limited number of financial institutions were engaged in mortgage financing. And even those institutions that are involved in full fledged mortgage financing would be secure and safe, because the LTV ratio is not that high, ranging from $20 \%$ to $40 \%$ on average in real terms. The term is also very short, averaging between three and five years at the maximum.

But if the current price spiral continues and spreads fast as it used to during the 2 nd quarter of 2003, it would certainly be disturbing. And that is why the government announced the "10.29 (October 29th, 2003) Measures" to prevent the bubble from further spreading and to contain it from ultimate bust. But price bubble is likely to reoccur any time, because those factors, as pointed above, which might cause the price bubble, remain unchecked as yet. Besides, the government has announced too many development plans and programs which may ignite another round of real estate bubble sooner or later.

Koreans are very much used to making capital gains through speculative transactions of real estate deals. There underlies a speculative mind among many Koreans, particularly among "the haves." Unless such a mind stops once and for all, there is always a chance for real estate price bubble to reemerge. Therefore, a monitoring system must be designed whereby one must closely watch the sign of price bubble and if such a symptom arises, one must activate the early warning mechanism. 


\section{Conclusion}

This study has led to the following conclusions. First, as the theory suggested, the housing prices spiral in Korea is attributable to excess demand and increasing cost of production, especially, land cost. However, the most significant finding is that the speculative demand is far more important than normal housing demand. In fact, the contribution of speculative demand to the determination of housing prices is much more important than that of normal housing demand. The surge of speculative housing demand since 2000 has been largely attributable to the trend of declining interest rate, rapidly increasin g money supply, and above all the government policy of economic recovery based on very liberal housing policy including the allowance of selling the pre-sale contract.

Second, the findings do show that there are bubbles in housing prices in Korea. However, the actual magnitude of bubbles varies widely depending upon the estimation methods used. By and large, the long-run equilibrium price approach produces the smallest amount of bubbles in comparison with the fundamental market value approach and the price-income ratio (PIR) approach. Third, contrary to what many might have thought, the seriousness of housing bubble in Korea is much less apparent than it was in Japan because of differences in basic market conditions, in particular, much lower level of loan to value ratio (LTV) and a greater degree of housing shortage prevailing in Korea since 2000 . To be more specific, it is unlikely that housing prices might fall as drastically as it did in Japan, and even if housing prices does fall, the low LTV ratio implies much smallerdanger of loan delinquency and banks' insolvency

These findings have interesting policy implications. First, the government should not repeat the policy conducive to speculation including the allowance of the sale of pre-sale contract and the politically motivated announcements of large housing construction projects including new town projects. Such announcements have often created an environment suitable for housing speculation. Second, the policy of increasing capital gains as an anti-speculative measure has its limitation because of low price elasticity of housing demand. Low demand price elasticity means forward shifting of the tax burden leading to housing prices hike. The capital gains tax is of course needed not only for government's tax receipts but also for better income distribution; but it is not a suitable way of discouraging speculative activities, unless it imposes a very heavy burden on the seller of house. If it carries a very heavy burden, then the supply of housing has the risk of being frozen. The best way of fighting speculation and stabilizing housing prices is to minimize the excess demand through the sustained increase of housing production on one hand, and, to cut down 
land cost through more aggressive land banking and well pre-planned land supply through better regional development planning on the other.

\section{References}

\section{1) In Korean language}

Choi, Hee Kap (2003.3), "The Trend Possibility of Bubble in Asset Prices," Samsung Research Institute

Chung, Hee Soo et al (1984), "Study of Housing Supply", Korea Research Institute for Settlement, Kookto Yunkoo, 84. 7

Daeshin Research Institute (2003.3), "Estimate of Real Estate Bubble: Apartment Price in Seoul"

Huh, Jae Wan (1991), "Empirical Study of Determinants of housing prices," Planning Review, Vol. 26, No. 2

Kang, Weon Chol, Kim, Bok Soon (1997.12), "Analysis of Land Price: Focus on Land Price Variation Since IMF'

Kang, Choong Ke and Chung, Chang Soo (2001.11), "Study of Dynamic Changes in housing prices," Planning Review, Vol.36, No.6

Kim, J eong Ho (1985), “Evaluation of Housing Policies: Empirical Analysis of Housing Demand", Hwang, M.C (ed), Housing Policy, Kyung Young Moonha-Won

Kim, Kap Sung, Park, Joo Young (2003.4), "Variation of housing prices by Region: Seoul and Surrounding Area", J ournal of the Korean Regional Association, p.47-61

Kim, Kyoung Hwan, Suh Seong Hwan (1990), "Real Estate Speculation and Price Bubble," Studies of Korea Economy, No. 4

Kim, Kyung Hwan, Suh, Seong Hwan and You, J in Bang (1991.12), “Empirical Study of Variation in Real EstatePrice and consumer Price Index," Bank of Korea, No. 36

Kim, Kap Sung and Suh, Seong Hwan (1999.12), “Empirical Analysis of Structural Change in the Real Estate Market," Samsung Economic Research Institute

Kim, Young Chul (1996), "Relationship between housing prices and Macro -Economic Variable," Planning Review, Vol. 31, No. 6, p.67-82 
Koo, Bong Chan (1998), "Determination of Apartment Price", Korea Housing Institute

Korea Deposit Insurance Corporation (2002.10), "Possibilities of Deflation and Financial Institute"

Lee, Hyun Woong, Lee Man Hyun (1999), "Determinants of housing prices in New Towns of the Seoul Metropolitan Area," Paper Series, Construction Technology Center, Choong-buk University, Vol 18, No. 1

Lee, Kyu Kwan, Kim, Kap Sung( 1996.4), “Impact of Land Regulation on the Supply of Land," Samsung Research Institute

Lee, Soo Young (1992), “Empirical Study of housing prices Variation, ,"Housing Finance

Lee, Young man (1995.8), "Determinants of Land Price in Korea", Yonsei University, Ph.D thesis

Oh, Kyu Sik, Lee Wang Ki (1997), "Weight of View in the Price of Apartment," Planning Review, Vol.32, No.3

Samsung Research Institute (2003.5), "Urgent Measures for the Stabilization of the Housing Market"

Samsung Research Institute (2003), CEO information, No. 402

Suh, Seong Hwan (1993.2), "Real Estate Price and Real Estate Policy", Housing Finance

Suh, Seong Hwan (1999), "Foreign Exchange Crisis and Change in the Pattern of Real Estate Price Variation," Housing Studies Review, Vol. 7, No. 2

Son, Jae Young, Kim, Kwang Young (1998.1), "The Characteristics and Outlook of Real Estate Price in Korea," Planning Review, Vol.33, No.1

Son, Jung Sik, Kim Kwan Young and Kim Young Joon (2003.5), "Forecast Model for Real Estate Price," Housing Studies Review, Vol.11, No.1, p.49-76 


\section{2) In English language}

Blanchard, Oliver J. nd Mark W. Watson (1982), "Bubbles, Rational Expectations, and Financial Markets," In Wachtel, Paul, ed., Crises in the Economic and Financial Structure, Lexington: D. C. Health and Co.

Bourassa, S. C., F. Hamelink, M. Hoesli and B. D. Macgregor (1999), Defining Housing Submarkets, Journal of Housing Economics, 8, pp.160-183

Capoza, D. R., G.M. Schwann and K.E. Case (1989), "The Asset Approach to Pricing Urban Land: Empirical Evidence," AREUEA J ournal, pp. 161-176

Chung, Joseph H. (1976), Cyclical Instability in Residential Construction in Canada, Economic Council of Canada

Englund, P and Y.M. Ioannides (1997), " housing prices Dynamics : An International Empirical Perspectives," J ournal of Housing Economics, Vol.6, No. 2, pp.119-136

Flood, Robert P, and Peter M. Garber (1980.8), "Market Fundamentals Ve rsus Price Level Bubbles: The First Tests," J ournal of Political Economy, Vol. 88, pp.745-770

Frankel, J effrey and Andrew Rose (1996), "Curre ncy Crashes in Emerging Markets: Empirical Indicators," J ournal of International Economics, Vol. 41, pp.351-366

Garber, Peter M. (1990. Spring), “Famous First Bubble," Journal of Economic Perspectives, Vol. 4, Issue 2, pp.35-54

Johansson, P-O (1987), The Economic Theory and Measurement of Environmental Benefit, Cambridge University Press.

Kim, Kyung Hwan, Lee Hang S. and Park, Young Joon (2003), "Real Estate Price Dynamics in Korea", Paper presenter at the Weimer School of Advanced Studies in Real Estate and Land Economics, May 17

Kindleberger, Charles P. (1978), Manias, Panics and Crashes : A History of Financial Crises, New York: Basic Books

Leroy, Stephen F. and Richard D. Porter (1981.5), "The Present Value Relation : Tests Based on Implied Variance Bounds," Econometrica, Vol. 49, No. 3, pp.555-574 
Shiller, Rober J. (1981.6), "Do Stock Prices Move Too Much to be Justified by Subsequent Changes in Dividends?" American Economics Review, Vol. 71, Issue 3, pp. 421-436

Stiglitz Joseph E. (1990), "Symposium on Bubbles", Journal of Economic Perspectives, Vol. 4, Issue 2, pp.13-18 